\title{
Etiology and clinical characteristics of SARS-CoV-2 and other human coronaviruses among children in Zhejiang Province, China 2017-2019
}

Yanjun Zhang ${ }^{1,2+}$, Lingxuan $\mathrm{Su}^{1 \dagger}$, Yin Chen ${ }^{2}$, Sicong Yu', Dan Zhang ${ }^{3}$, Haiyan Mao ${ }^{2}$ and Lei Fang ${ }^{2^{*}}$ (1)

\begin{abstract}
Background: A novel coronavirus (SARS-CoV-2) emerging has put global public health institutes on high alert. Little is known about the epidemiology and clinical characteristics of human coronaviruses infections in relation to infections with other respiratory viruses.

Methods: From February 2017 to December 2019, 3660 respiratory samples submitted to Zhejiang Children Hospital with acute respiratory symptoms were tested for four human coronaviruses RNA by a novel two-tube multiplex reverse transcription polymerase chain reaction assays. Samples were also screened for the occurrence of SARS-CoV-2 by reverse transcription-PCR analysis.
\end{abstract}

Results: Coronavirus RNAs were detected in 144 (3.93\%) specimens: HCoV-HKU1 in 38 specimens, HCoV-NL63 in 62 specimens, HCoV-OC43 in 38 specimens and HCoV-229E in 8 specimens. Genomes for SARS-CoV-2 were absent in all specimens by RT-PCR analysis during the study period. The majority of HCoV infections occurred during fall months. No significant differences in gender, sample type, year were seen across species. 37.5 to $52.6 \%$ of coronaviruses detected were in specimens testing positive for other respiratory viruses. Phylogenic analysis identified that Zhejiang coronaviruses belong to multiple lineages of the coronaviruses circulating in other countries and areas.

Conclusion: Common HCoVs may have annual peaks of circulation in fall months in the Zhejiang province, China. Genetic relatedness to the coronaviruses in other regions suggests further surveillance on human coronaviruses in clinical samples are clearly needed to understand their patterns of activity and role in the emergence of novel coronaviruses.

Keywords: Human coronavirus, Hospitalized children, Phylogenic analysis, Acute respiratory infection, SARS-CoV-2

\section{Introduction}

Human coronaviruses (HCoVs) are common viruses that cause mild to severe respiratory infections. To date, there are seven CoVs have been confirmed to infect human,

\footnotetext{
*Correspondence: Ifang@cdc.zj.cn

${ }^{\dagger}$ Yanjun Zhang and Lingxuan Su contributed equally to this work.

${ }^{2}$ Zhejiang Provincial Center of Disease Control and Prevention, 3399 Bincheng Road, Hangzhou 310051, China

Full list of author information is available at the end of the article
}

including two $\alpha$-CoVs (HCoV-229E and HCoV-NL63) and five $\beta$-CoVs [HCoV-HKU1, HCoV-OC43, severe acute respiratory syndrome coronavirus (SARS-CoV) and SARS-CoV-2, and Middle East respiratory syndrome coronavirus (MERS-CoV)] [1]. The ongoing pandemic of COVID-19 offers the most recent example of the tragedy when highly pathogenic coronaviruses emerge in the human population [2-4]. As of 23 March 2021, approximately 25 million cases have been reported to the WHO 
accounting for a $2.2 \%$ case fatality rate. Over the last two decades, the emergence of Severe Acute Respiratory Syndrome Coronavirus (SARS-CoV) has been associated with severe atypical pneumonia and caused 774 deaths [5]. In 2012, a man in Saudi Arabia who infected by Middle East Respiratory Syndrome Coronavirus (MERS$\mathrm{CoV}$ ) died of acute pneumonia and renal failure [6]. The continuing spread of MERS-CoV resulted in unprecedented outbreaks and high case-fatality rates.

HCoV-NL63, HCoV-HKU1, HCoV-229E, and HCoVOC43 circulate worldwide and cause a range of respiratory symptoms [7]. These four $\mathrm{HCoVs}$ result in $30 \%$ of common colds and acute respiratory infections such as pneumonia and bronchiolitis, especially in immunocompromised children $[8,9]$. Lower respiratory tract infections are considered as the most common cause of death among children and are responsible for $15 \%$ mortality rate of children under 5 years of age globally [10, $11]$. HCoVs pose serious threats to children health as they are associated with acute upper or lower respiratory tract infections $[12,13]$. Although HCoVs are distributed globally, the predominant species may vary by region or year. Moreover, a notable feature of COVID-19 pandemic is the relative paucity of published report that describes the potential impact of SARS-CoV-2 on children with acute respiratory infection [14]. However, the prevalence and clinical profiles of HCoVs have been largely underdetermined and no studies described circulation of SARS$\mathrm{CoV}-2$ and four common $\mathrm{HCoVs}$ across multiple years in Zhejiang province, China.

Considering the discovery of novel SARS-CoV-2, we retrospectively investigated the role of SARS-CoV-2 and common human coronaviruses $(\mathrm{HCoV}-229 \mathrm{E}, \mathrm{HCoV}-$ OC43, HCoV-NL63 and HCoV-HKU1) in childhood respiratory infections in Zhejiang province, China, and results were compared to data for other viral respiratory pathogens including influenza $\mathrm{A}$ and $\mathrm{B}$, parainfluenza, respiratory syncytial virus, rhinovirus, and adenovirus.

\section{Materials and methods}

\section{Ethical approval statement}

The studies involving human participants were reviewed and approved by Zhejiang Provincial Center for Disease Control and Prevention of ethics committee. Children's parents/guardians have been notified the purpose of the study and the right to keep information confidential. Children's parents/guardians provided their written informed consent to participate in this study.

\section{Sample collection}

A total of 3660 retrospective respiratory samples were collected from children (age, $\leq 18$ years) with acute respiratory tract infections who admitted to Children's
Hospital of Zhejiang University from 2017 to 2019. Written informed consent was obtained from the guardians of all participants before specimens and data collection. Specimens were collected in accordance with Zhejiang Provincial CDC guidance and contained nasopharyngeal swab $(n=26)$, sputum $(n=3590)$ and bronchoalveolar lavage $(n=41) .2138$ samples were from male and the remaining were from female. Clinical specimens were initially kept in sterile EP tube with $5 \mathrm{~mL}$ viral transport medium (Becton, Dickinson and Company, NJ) and then transferred to Zhejiang Provincial CDC within the same day for routine monitoring. All clinical samples were stored at $-80^{\circ} \mathrm{C}$ prior to blinded analysis. Clinical data including symptoms, history of illness, severity of infection, demographic data, drug usage and laboratory examination were recorded for each patient and reviewed retrospectively when patients confirmed with $\mathrm{HCoV}$ infections.

\section{Nucleic acid extraction}

Viral nucleic acid was extracted from $200 \mu \mathrm{L}$ of clinical specimens using QIAGEN Cador Pathogen 96 QIAcube HT Kit (Qiagen, Hilden, German) and following manufacturer's instructions. The extracts were eluted into 50 $\mu \mathrm{L}$ of DNase- and RNase-free water and stored at $-80^{\circ} \mathrm{C}$ until used as a template for PCR assay.

\section{Two-tube multiplex reverse transcription PCR (RT-PCR) assay}

A two-tube multiplex RT-PCR assay (a two-tube assay) was performed for the identification of sixteen respiratory virus using virus-specific primers as described previously [15]. Briefly, one tube was added with nine pairs of chimeric primers for the detection of nine viruses (HRV, FluA, FluB, 229E, OC43, HKU1, PIV1, PIV3 and ADV), and the other tube was added with eight pairs of chimeric primers to detect another eight viruses (RSVA, RSVB, NL63, PIV2, PIV4, H3N2, H1N1 and HBoV). The primer sequences, target genes, amplicon sizes and primer working concentrations were summarized in Additional file 1: Table 1. Qiagen one-step RT-PCR Kit (Qiagen, Hilden, German) was used for amplification. A final volume of $25 \mu \mathrm{L}$ PCR mixture containing $2 \mu \mathrm{L}$ of template, $1 \mu \mathrm{L}$ of primer-mix (mixture was prepared according to the primer working concentration in Table 1), $1 \mu \mathrm{L}$ of enzyme-mix, $1 \mu \mathrm{L}$ of deoxinucleotidetriphospate (dNTP), $5 \mu \mathrm{L}$ of $5 \mathrm{X}$ buffer, $1 \mu \mathrm{L}$ of Taq polymerase was subjected to multiplex RT-PCR screening. The amplification cycle was initial denaturation at $50{ }^{\circ} \mathrm{C}$ for $30 \mathrm{~min}, 95^{\circ} \mathrm{C}$ for $15 \mathrm{~min}$, followed by 10 cycles of $95^{\circ} \mathrm{C}$ for $30 \mathrm{~s}, 55^{\circ} \mathrm{C}$ for $30 \mathrm{~s}, 72{ }^{\circ} \mathrm{C}$ for $30 \mathrm{~s} ; 10$ cycles of $95^{\circ} \mathrm{C}$ for $30 \mathrm{~s}, 65^{\circ} \mathrm{C}$ for $30 \mathrm{~s}, 72{ }^{\circ} \mathrm{C}$ for $30 \mathrm{~s} ; 25$ cycles of $95^{\circ} \mathrm{C}$ for $30 \mathrm{~s}, 48^{\circ} \mathrm{C}$ for $30 \mathrm{~s}, 72{ }^{\circ} \mathrm{C}$ for $30 \mathrm{~s}$ and one final extension at $72{ }^{\circ} \mathrm{C}$ for 
Table 1 Distribution of 16 respiratory virus in children according to gender and age

\begin{tabular}{|c|c|c|c|c|c|c|c|}
\hline & \multirow[t]{2}{*}{ Total, n (\%) } & \multicolumn{2}{|c|}{ Gender, n (\%) } & \multicolumn{4}{|l|}{ Age, n (\%) } \\
\hline & & Male & Female & $0-1 Y$ & $1 Y-2 Y$ & $2 Y-10 Y$ & $10 Y-18 Y$ \\
\hline \multicolumn{8}{|l|}{ Sample } \\
\hline Total sample & 3660 & $2138(58.42)$ & $1498(40.93)$ & $2694(73.61)$ & $311(8.50)$ & $552(15.08)$ & $79(2.16)$ \\
\hline Positive sample & $1773(48.44)$ & $1091(51.03)$ & $673(44.93)$ & $1429(53.04)$ & $129(41.48)$ & $184(33.33)$ & $20(25.32)$ \\
\hline Human coronavirus (HCoV) & $144(3.93)$ & $86(4.02)$ & $58(3.87)$ & $114(4.23)$ & $12(3.86)$ & $14(2.54)$ & $4(5.06)$ \\
\hline HKU1 & $38(1.04)$ & $24(1.12)$ & $14(0.93)$ & $31(1.15)$ & $1(0.32)$ & $5(0.91)$ & $1(1.27)$ \\
\hline NL63 & $62(1.69)$ & $35(1.64)$ & $27(1.80)$ & $47(1.74)$ & $7(2.25)$ & $6(1.09)$ & $2(2.53)$ \\
\hline OC43 & $38(1.04)$ & $25(1.17)$ & $13(0.87)$ & $33(1.22)$ & $4(1.29)$ & $1(0.18)$ & 0 \\
\hline $229 E$ & $8(0.22)$ & $3(0.14)$ & $5(0.33)$ & $5(0.19)$ & 0 & $2(0.36)$ & $1(1.27)$ \\
\hline SARS-CoV-2 & 0 & 0 & 0 & 0 & 0 & 0 & 0 \\
\hline Influenza (Flu) & $242(6.61)$ & $155(7.25)$ & $84(5.61)$ & $182(6.76)$ & $15(4.82)$ & $38(6.88)$ & $4(5.06)$ \\
\hline FluA & $132(3.61)$ & $87(4.07)$ & $44(2.94)$ & $104(3.86)$ & $9(2.89)$ & $16(2.90)$ & $2(2.53)$ \\
\hline FluB & $116(3.17)$ & $74(3.46)$ & $39(2.60)$ & $82(3.04)$ & $7(2.25)$ & $22(3.99)$ & $2(2.53)$ \\
\hline Respiratory syncytial virus (RSVs) & $531(14.51)$ & $330(15.43)$ & $197(13.15)$ & $452(16.78)$ & $27(8.68)$ & $40(7.24)$ & $6(7.59)$ \\
\hline RSVA & $366(10.00)$ & $223(10.43)$ & $142(9.48)$ & $307(11.40)$ & $25(8.04)$ & $23(4.17)$ & $6(7.59)$ \\
\hline RSVB & $168(4.59)$ & $115(5.38)$ & $52(3.47)$ & $155(5.75)$ & $4(1.28)$ & $8(1.45)$ & 0 \\
\hline Parainfluenza (PIVs) & $401(10.96)$ & $243(11.37)$ & $158(10.55)$ & $338(12.55)$ & $34(10.93)$ & $29(5.25)$ & 0 \\
\hline PIV1 & $37(1.01)$ & $28(1.31)$ & $9(0.60)$ & $30(1.11)$ & $3(0.96)$ & $4(0.72)$ & 0 \\
\hline PIV2 & $18(0.49)$ & $11(0.51)$ & $7(0.47)$ & $12(0.45)$ & $2(0.64)$ & $4(0.72)$ & 0 \\
\hline PIV3 & $338(9.23)$ & $204(9.54)$ & $134(8.95)$ & $286(10.62)$ & $28(9.00)$ & $24(4.35)$ & 0 \\
\hline PIV4 & $12(0.33)$ & $6(0.28)$ & $6(0.40)$ & $9(0.33)$ & 0 & $3(0.54)$ & 0 \\
\hline Human rhinovirus (HRV) & $503(13.74)$ & $311(14.55)$ & $190(12.68)$ & $383(14.22)$ & $44(14.15)$ & $65(11.78)$ & $9(11.39)$ \\
\hline Human metapneumovirus (HMPV) & $111(3.03)$ & $59(2.76)$ & $52(3.47)$ & $101(3.75)$ & $4(1.29)$ & $5(0.91)$ & 0 \\
\hline Human bocavirus (HBoV) & $63(1.72)$ & $34(1.59)$ & $28(1.87)$ & $43(1.60)$ & $12(3.86)$ & $7(1.27)$ & 0 \\
\hline Human adenovirus (ADV) & $140(3.83)$ & $89(4.16)$ & $51(3.40)$ & $92(3.41)$ & $17(5.47)$ & $29(5.25)$ & $2(2.53)$ \\
\hline
\end{tabular}

3 min. The amplified fragment $(15 \mu \mathrm{L})$ was separated on the QIAxcel automatic electrophoresis using QIAxcel DNA High-Resolution kit and confirmed as specific virus types following reference marker in the system.

The specificity of the two-tube assay was based on the automatic electrophoresis. All positive controls were observed and separated clearly from the other viral targets and no primer dimer was observed in either tube. The expected size of each virus type/subtype-specific amplicon was listed in Additional file 1: Table 1. The detection sensitivity in tube 1 and tube 2 was 2000 and 200 copies per reaction, respectively. The detection limit for HRV, PIV2, PIV3, RSVA, HBoV and ADV was 20 copies per reaction and the remaining 10 viruses had a detection limit of 200 copies per reaction.

\section{Detection of SARS-CoV- 2 by RT-qPCR}

SARS-CoV-2 nucleic acid detection kit (Daan, China) was applied to detect the ORF1ab gene and $\mathrm{N}$ gene of SARS-CoV-2 according to protocols as described previously [16]. Primers and probes used for SARS-CoV-2 were listed in Additional file 1: Table 1. The reaction was performed in a $25 \mu \mathrm{L}$ reaction mixture containing $17 \mu \mathrm{L}$ of reaction mixture $\mathrm{A}, 3 \mu \mathrm{L}$ of reaction mixture $\mathrm{B}$ and 5 $\mu \mathrm{L}$ of RNA. The RT-qPCR reactions were performed with initial one cycle at $50^{\circ} \mathrm{C}$ for $15 \mathrm{~min}$ and $95^{\circ} \mathrm{C}$ for $15 \mathrm{~min}$, following by 45 cycles of $94^{\circ} \mathrm{C}$ for $15 \mathrm{~s}$ and $55^{\circ} \mathrm{C}$ for $45 \mathrm{~s}$. All RT-qPCRs were performed on the 7500 Fast RealTime PCR system (Applied Biosystems) and all samples were analyzed in duplicate.

\section{Sequencing of spike (S) gene}

The S genes of HKU1, OC43, NL63 and 229E positive samples were amplificated using PrimeScript ${ }^{\mathrm{TM}}$ One Step RT-PCR Kit Ver.2 (TaKaRa 055RA). The volume of PCR mixture was $25 \mu \mathrm{L}$, containing buffer $12.5 \mu \mathrm{L}$, enzymemix $1 \mu \mathrm{L}$, forward primer $0.5 \mu \mathrm{L}$, reverse primer 0.5 $\mu \mathrm{L}$, RNA $5 \mu \mathrm{L}$, and Rnase free water $5.5 \mu \mathrm{L}$. Their forward and reverse primers were listed in Additional file 1: Table 2. The amplification cycle was reverse transcription at $50{ }^{\circ} \mathrm{C}$ for $30 \mathrm{~min}$ and initial denaturation at $94{ }^{\circ} \mathrm{C}$ for 2 min, followed by 40 cycles of $94{ }^{\circ} \mathrm{C}$ for $45 \mathrm{~s}, 50-56{ }^{\circ} \mathrm{C}$ (depending on species) for $30 \mathrm{~s}, 72{ }^{\circ} \mathrm{C}$ for $45 \mathrm{~s}$, and one final extension at $72{ }^{\circ} \mathrm{C}$ for $10 \mathrm{~min}$ at the end of 40 cycles. Amplified PCR products were sequenced by Sanger sequencing method (TsingKe Biological Technology). 
Table 2 Viral detection rate according to sample type

\begin{tabular}{|c|c|c|c|c|}
\hline Virus & Total, n (\%) & Nasopharyngeal swab, n (\%) & $\begin{array}{l}\text { Bronchoalveolar lavage, } n \\
\text { (\%) }\end{array}$ & Sputum, n (\%) \\
\hline \multicolumn{5}{|l|}{ Sample } \\
\hline Total sample & 3660 & $26(0.71)$ & $41(1.12)$ & $3590(98.09)$ \\
\hline Positive sample & $1773(48.44)$ & $13(50.00)$ & $22(53.66)$ & $1738(48.41)$ \\
\hline Human coronavirus (HCoV) & $144(3.93)$ & $1(3.85)$ & $2(4.88)$ & $141(3.93)$ \\
\hline HKU1 & $38(1.04)$ & 0 & 0 & $38(1.06)$ \\
\hline NL63 & $62(1.69)$ & $1(3.85)$ & $2(4.88)$ & $59(1.64)$ \\
\hline OC43 & $38(1.04)$ & 0 & 0 & $38(1.06)$ \\
\hline $229 \mathrm{E}$ & $8(0.22)$ & 0 & 0 & $8(0.22)$ \\
\hline SARS-CoV-2 & 0 & 0 & 0 & 0 \\
\hline
\end{tabular}

\section{Phylogenetic analysis}

DNA sequences were concatenated manually and aligned by Clustal W and downloaded to MEGA 7.0 to generate a phylogenetic tree constructed by neighbor-joining algorithm and jukes-cantor model with 1000 bootstrap. Genome sequences of other coronaviruses were retrieved from GeneBank and included in phylogenetic analysis for comparison.

\section{Statistical analysis}

The statistical software SPSS (Statistics 20, IBM, Armonk, NY) was used for data processing and statistical analysis. Fisher's Chi-square test was performed to test for statistically significant associations between prevalence of human coronaviruses to season, age, patient gender, other respiratory viruses, and clinical sample type. $P$ values of $<0.05$ were considered as significant. Analyses of variance (ANOVAs) were also performed to test the null hypothesis that there was no difference between clinical manifestations and $\mathrm{HCoVs}$ infection. If a null hypothesis was rejected at the 0.05 level, a Tukey's multiple-comparison test was used to identify differences in clinical characteristics.

\section{Results}

\section{Prevalence of four human coronaviruses in Zhejiang} Province, China

To survey human coronaviruses (HCoVs) in Zhejiang province, nasopharyngeal swabs $(n=26)$, sputum $(n=3593)$ and bronchoalveolar-lavage fluid $(n=41)$ specimens were collected periodically between February 2017 and December 2019 from children with respiratory symptoms. Overall, all clinical specimens were negative for SARS-CoV-2 RNA by RT-PCR analysis. 38 (1.04\%) were positive for HCoV-HKU1, 62 (1.69\%) for HCoV-NL63, 8 (0.22\%) for HCoV-229E and 38 (1.04\%) for $\mathrm{HCoV}-\mathrm{OC} 43$ (Table 1). Comparison of the percentage of positive samples for multiple respiratory viruses was used to infer prevalence (Fig. 1). Respiratory syncytial viruses (RSVA + RSVB, 14.51\%), human rhinovirus (HRV, 13.74\%), parainfluenza (PIVs 1-4, 10.96\%) and influenza (FluA + FluB, 6.61\%) were the four dominant viruses in Zhejiang area, which were detected more frequently than HCoVs $(P<0.001)$.

\section{Circulation trend}

Overall, $\mathrm{HCoVs}$ dominant circulation season was in the transition of summer to fall, especially August to October (Fig. 2). The percent of $\mathrm{HCoV}$ positive tests varied seasonally throughout each year and the percent positive also varied annually by $\mathrm{HCoV}$ species (Fig. 3a). The detection rates of $\mathrm{HCoVs}$ were $2.18 \%, 3.94 \%, 4.51 \%, 5.22 \%$ of winter, spring, summer and autumn, respectively (Fig. 3b). $\mathrm{HCoV}-\mathrm{HKU} 1$ demonstrated a distinct peak each of the three years, with a relatively large peak in Spring 2018. For $\mathrm{HCoV}$ - NL63, in contrast to the pattern described for $\mathrm{HCoV}-\mathrm{HKU} 1$, the peak detection frequency occurred in the third season. $51.61 \%$ of positive $\mathrm{HCoV}$ - NL63 samples were detected between September to November. $\mathrm{HCoV}-\mathrm{OC} 43$ also demonstrated a consistent detection frequency between seasons, with the testing peak occurring each year in spring. The exception was $\mathrm{HCoV}-229 \mathrm{E}$,



Fig. 1 The detection rates of respiratory viruses 


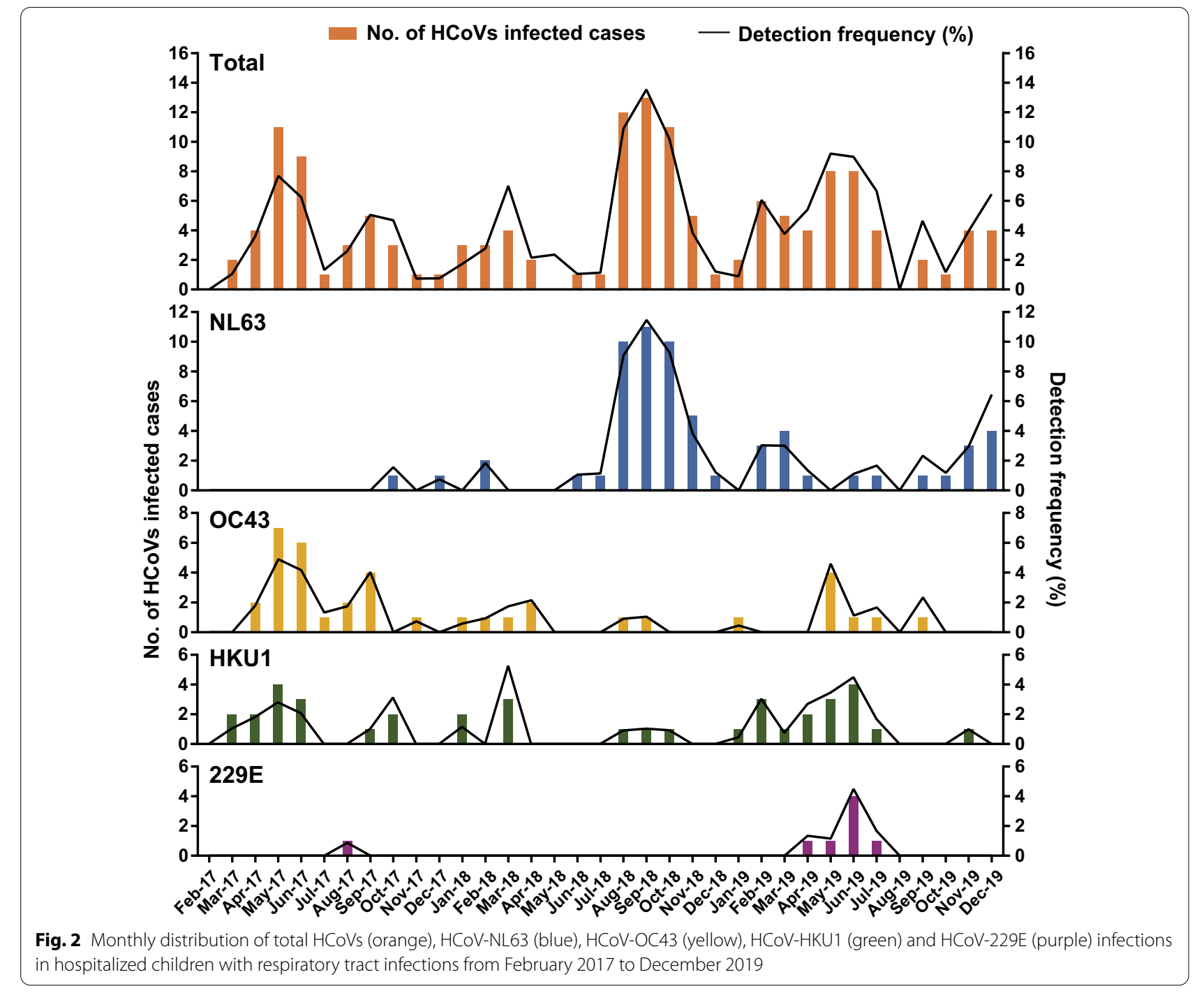

as $87.50 \%$ of detectable $\mathrm{HCoV}-229 \mathrm{E}$ were found in the spring and summer of 2019. To be noted, HCoV-229E detected only in spring and summer through the study period, and no HCoV-229E was detected in 2018.

\section{Clinical profiles associated with $\mathrm{HCoV}$ infections}

Almost all HCoV-positive patients (143/144, 99.31\%) had lower respiratory tract infections. The incidence of lower respiratory tract infections in patients with $\mathrm{HCoVs}$ (3.94\%) infection was significantly lower than that of patients infected with RSV (14.51\%), PIV (10.96\%), or HRV (13.85\%). In addition, only one patient infected with HCoV-NL63 was diagnosed with an upper respiratory tract infection from nasopharyngeal swab in this study. The positive rate of $\mathrm{HCoV}$ infections was $3.85 \%(1 / 26)$ for nasopharyngeal swab, $4.88 \%$ (2/41) for bronchoalveolar lavage and $3.93 \%(141 / 3590)$ for sputum $(P>0.05)$ (Table 2). The four investigated $\mathrm{HCoV}$ subtypes were detected in sputum samples, while only HCoV-NL63 infections were positive in nasopharyngeal swab and bronchoalveolar lavage specimens.

Fever, cough, expectoration and sore throat were the common clinical presentations with $\mathrm{HCoV}$ infections, among which cough $(47.22 \%)$, sore throat $(40.97 \%)$ and fever (23.61\%) were the top three manifestations (Fig. 4a). Difficulty in breathing and respiratory failure were seen in patients who infected with $\mathrm{HCoV}-\mathrm{OC} 43$. Slightly more patients with $\mathrm{HCoV}$ infections were males but no significant difference was in the sex distribution between the four species $(P>0.2)$ (Table 1$)$. Age distribution of patients differed between $\mathrm{HCoV}$ species and infants ( $<1$ year old) with weak respiratory immunity were most susceptible to four types of HCoVs infections (Fig. 4b). To be noted, HCoV-229E had a higher detection proportion in children between 2 and 18 years old compared to HCoV-OC43, HCoV-NL63, and HCoV-HKU1. 


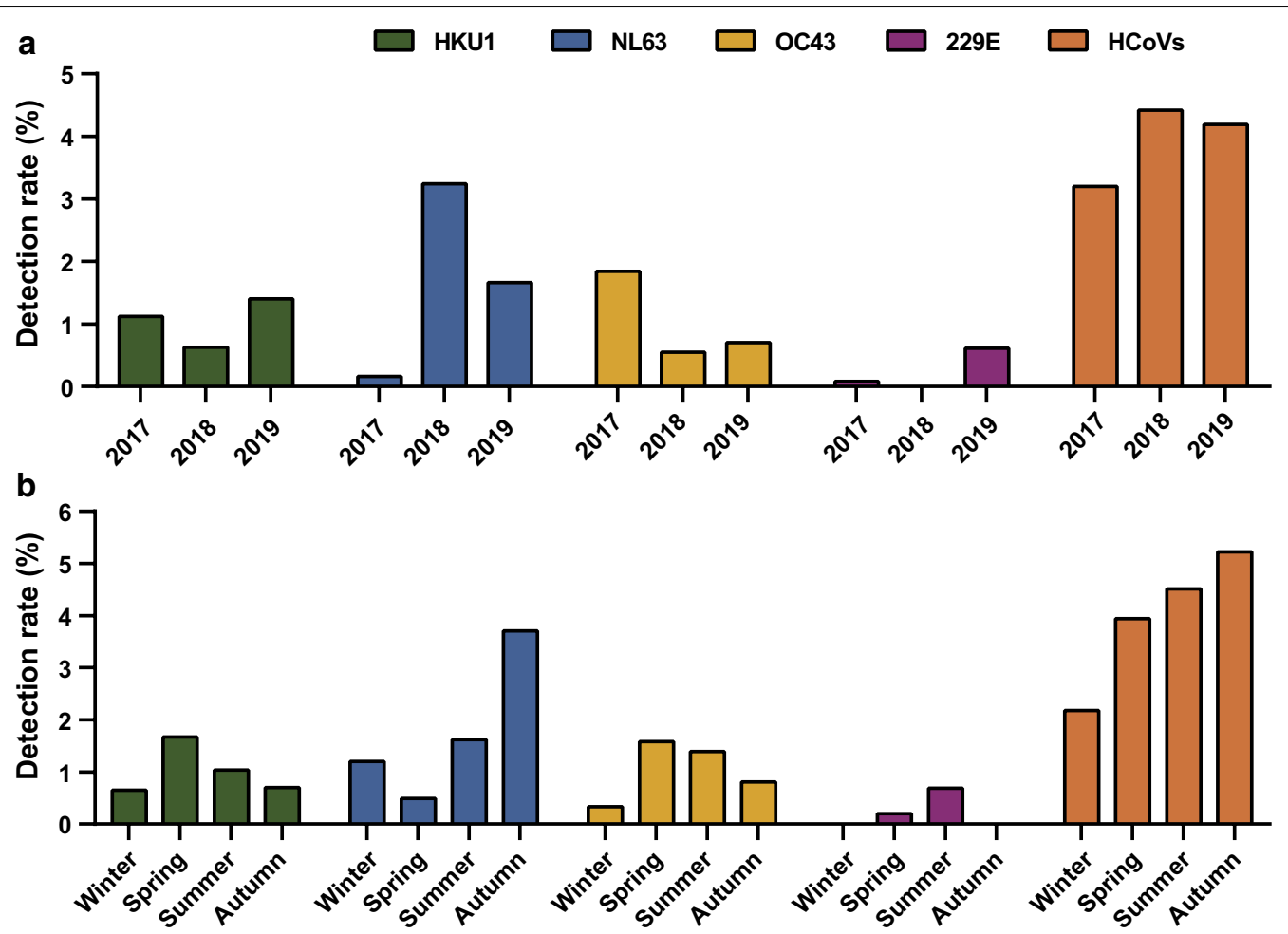

Fig. 3 Circulation trends of HCoV infections. a Yearly distribution of the four HCoV infections. $\mathbf{b}$ Seasonal distribution of the four HCoV infections

\section{Coinfection of respiratory viruses}

High rates of coinfection with other respiratory viruses were observed for all coronaviruses, with the coinfection rates of $\mathrm{HCoV}-\mathrm{HKU} 1, \mathrm{HCoV}-\mathrm{NL} 63, \mathrm{HCoV}-\mathrm{OC} 43$ and $\mathrm{HCoV}-229 \mathrm{E}$ as $44.74 \%$ (17/38), 43.55\% (27/62), 52.63\% $(20 / 38)$ and $37.50 \%(3 / 8)$, respectively (Table 3$)$. Among the 146 positive detections, $54.11 \%$ reported a single $\mathrm{HCoV}$ species detection only, $1.37 \%$ reported two $\mathrm{HCoV}$ species, and $44.52 \%$ detected another respiratory virus. The most common $\mathrm{HCoV}$ co-infections were $\mathrm{HCoV}$ HKU1 with $\mathrm{HCoV}-229 \mathrm{E}$ (2 specimens, 1.37\%). Of all samples testing positive for coronavirus, $40 \%$ samples were coinfected with HRV. The most common co-detected non-HCoVs were human adenovirus (40.71\%), human rhinovirus/bocavirus (37.57\%), and human metapneumovirus (32.43\%).

\section{Phylogenetic analysis of HCoV strains}

Phylogenetic trees were further constructed based on the sequencing of $\mathrm{HCoV}$ spike genes. A representative subset of HCoV-OC43 $(n=13)$, HCoV-NL63 $(n=8)$ and $\mathrm{HCoV}-\mathrm{NL} 63(\mathrm{n}=8)$ were included in the phylogenetic analysis and compared to the $\mathrm{HCoVs}$ from clinical sources worldwide. A high level of genetic diversity was observed among those HCoVs. The OC43 coronaviruses were clustered into genotype $\mathrm{G}(9,69.23 \%)$ and genotype
B $(4,30.77 \%)$ and related to the sequences detected in Malaysia and Beijing, respectively (Fig. 5a). No significant differences were observed between $\mathrm{HCoV}-\mathrm{OC} 43$ strains identified in different years. Similarly, HCoV-NL63 strains in this study were clustered into genotype B (5, $62.5 \%)$ and genotype $C(3,37.5 \%)$ and shown close identity to the viruses isolated from China and USA (Fig. 5b). Moreover, the phylogenetic tree of the HCoV-HKU1 isolates shown the existence of two major clusters that contained both Hong Kong and France strains of $\mathrm{HCoV}$ HKU1 (Fig. 5c). All HCoV-HKU1 subtypes isolated from 2017 were grouped into genotype B.

\section{Discussion}

Emerging and reemerging pathogens represent a serious burden to global health. The recent emergence of SARSCoV-2 clearly demonstrated the epidemic potential of coronaviruses. Here we demonstrated that $\mathrm{HCoV}-\mathrm{OC} 43$, $\mathrm{HCoV}-\mathrm{NL63}$, HCoV-HKU1 and HCoV-229E were specifically associated with lower respiratory tract disease in pediatric population, accounting for $3.93 \%$ of all admissions for acute respiratory infections. Only one patient was associated with upper respiratory traction infection from nasopharyngeal swab samples. The newly discovered SARS-CoV-2 RNA was absent in all tested samples, suggesting no introduction of this highly pathogenic 

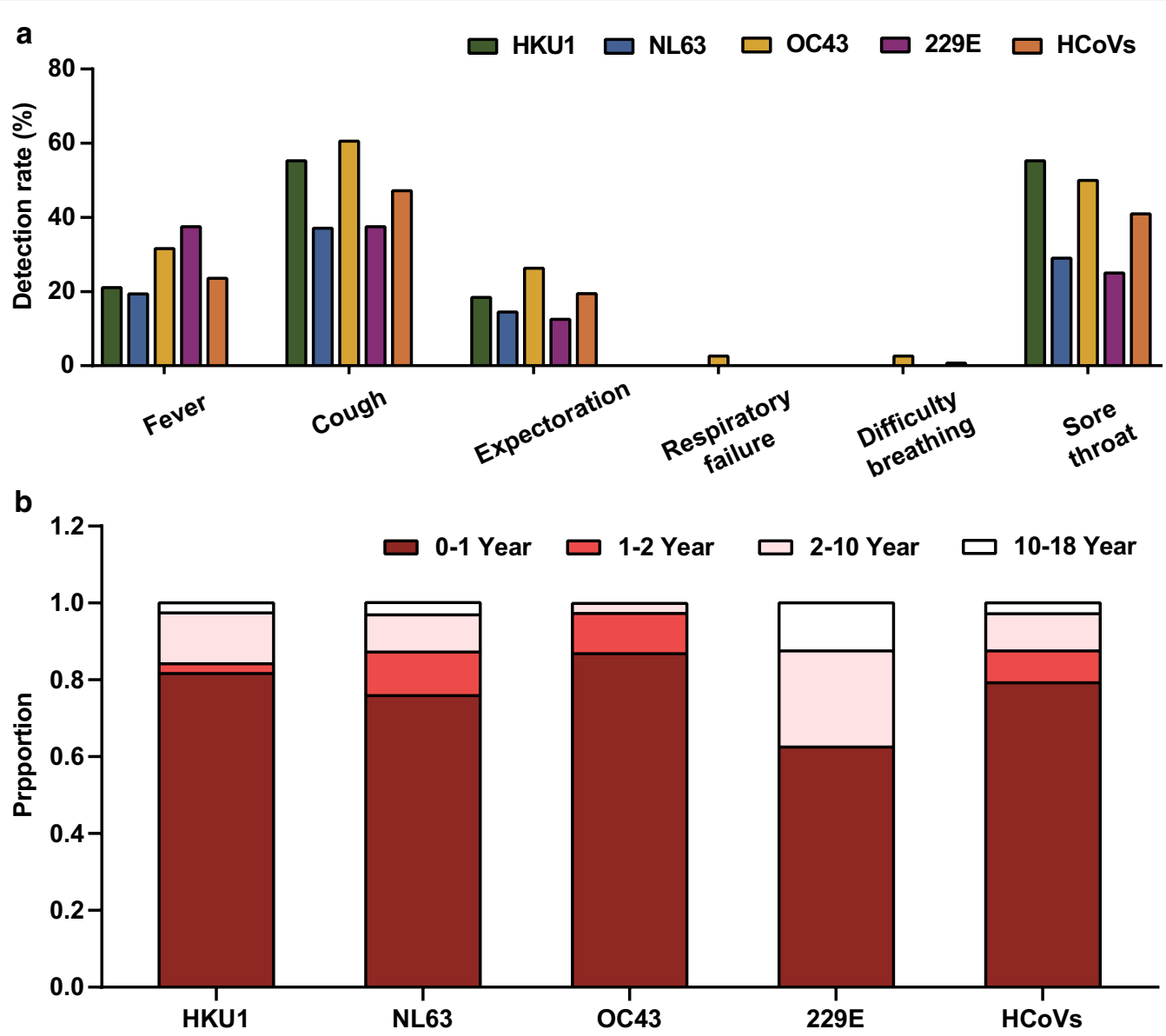

Fig. 4 Clinical profiles of HCoV infections based on clinical manifestation (a) and age (b)

Table 3 Coinfection of 16 respiratory virus

\begin{tabular}{|c|c|c|c|c|c|c|c|c|c|c|c|c|c|}
\hline \multirow[t]{2}{*}{ Virus } & \multicolumn{12}{|c|}{ Number of cases } & \multirow[t]{2}{*}{ Rate $(\%)$} \\
\hline & HKU1 & NL63 & OC43 & $229 E$ & SARS-CoV-2 & Flu & RSVs & PIVs & HRV & HMPV & HBoV & ADV & \\
\hline HKU1 & 38 & 0 & 0 & 2 & 0 & 0 & 4 & 5 & 4 & 0 & 2 & 0 & 1.04 \\
\hline NL63 & & 62 & 0 & 0 & 0 & 5 & 4 & 2 & 16 & 1 & 2 & 1 & 1.69 \\
\hline OC43 & & & 38 & 0 & 0 & 3 & 5 & 7 & 6 & 2 & 1 & 2 & 1.04 \\
\hline $229 \mathrm{E}$ & & & & 8 & 0 & 0 & 0 & 1 & 0 & 0 & 0 & 0 & 0.22 \\
\hline SARS-CoV-2 & & & & & 0 & 0 & 0 & 0 & 0 & 0 & 0 & 0 & 0 \\
\hline Flu & & & & & & 242 & 18 & 14 & 11 & 2 & 2 & 10 & 6.61 \\
\hline RSVs & & & & & & & 531 & 26 & 70 & 5 & 4 & 12 & 14.51 \\
\hline PIVs & & & & & & & & 401 & 51 & 10 & 2 & 13 & 10.96 \\
\hline HRV & & & & & & & & & 503 & 10 & 9 & 13 & 13.74 \\
\hline HMPV & & & & & & & & & & 111 & 1 & 5 & 3.03 \\
\hline $\mathrm{HBOV}$ & & & & & & & & & & & 63 & 1 & 1.72 \\
\hline ADV & & & & & & & & & & & & 140 & 3.83 \\
\hline One virus & 21 & 35 & 18 & 5 & 0 & 181 & 399 & 275 & 314 & 75 & 39 & 83 & 39.48 \\
\hline Two viruses & 17 & 23 & 14 & 3 & 0 & 52 & 113 & 109 & 166 & 29 & 19 & 43 & 8.03 \\
\hline Three viruses & 0 & 4 & 6 & 0 & 0 & 9 & 18 & 16 & 22 & 7 & 5 & 13 & 0.90 \\
\hline Four viruses & 0 & 0 & 0 & 0 & 0 & 0 & 1 & 1 & 1 & 0 & 0 & 1 & 0.03 \\
\hline
\end{tabular}




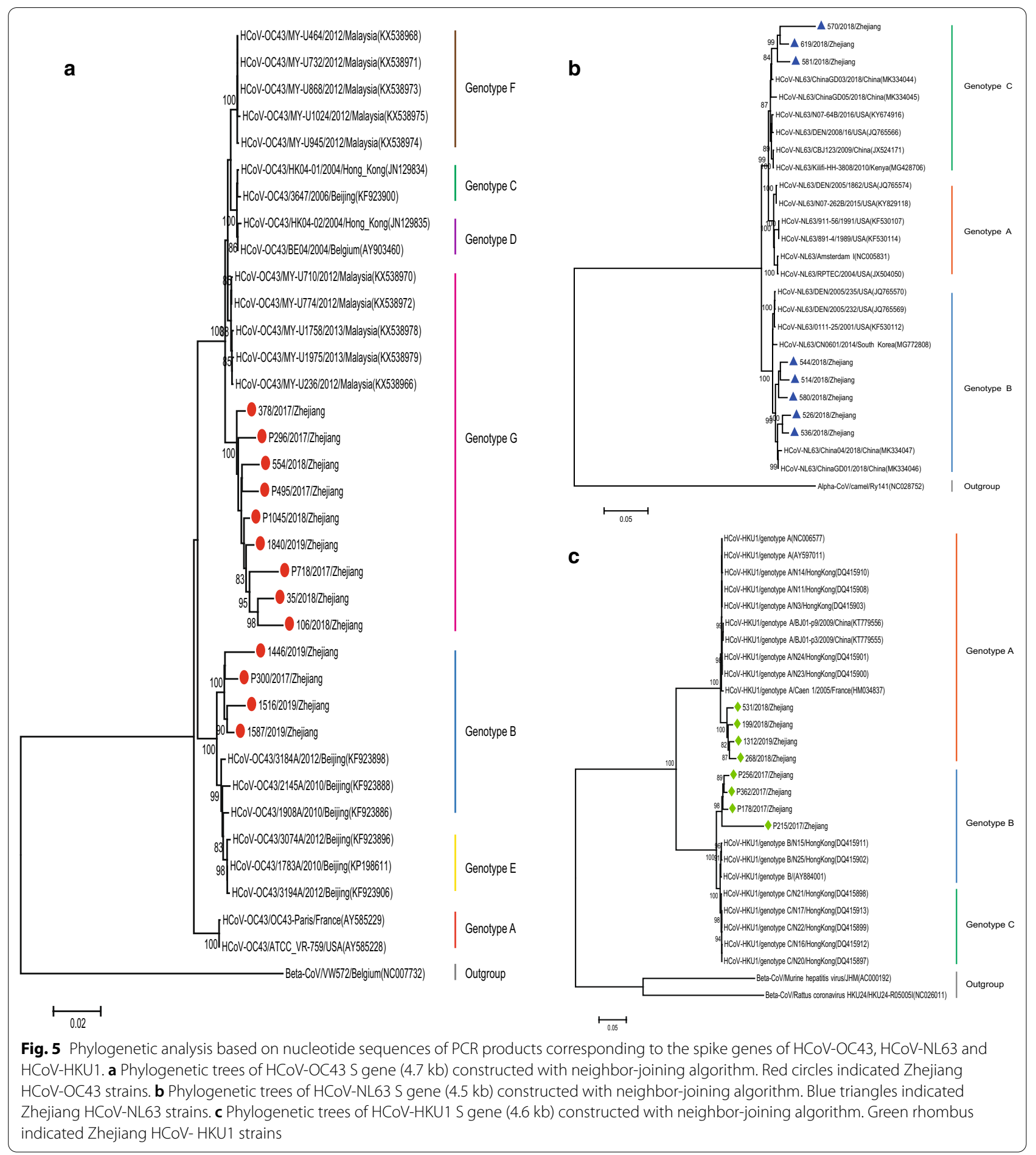

coronavirus into the Zhejiang population before 2020 . RSV (14.51\%) was the predominant respiratory virus in our pediatric population. Our results aligned with studies conducted in other countries whereby RSV was the predominant viral agent among young children [17-20]. All the HCoVs detected have been subtyped. HCoV-NL63 $(1.69 \%)$ was the most prevalent coronaviruses in our study consistent with reports in Hong Kong [21], Japan [22], Brazil [23] and Kenya [24], but some studies demonstrated the occurrence of $\mathrm{HCoV}-\mathrm{OC} 43$ was similar or 
even higher than that of HCoV-NL63 in United States [9], United Kingdom [25] and Guangdong province [26].

In general, common $\mathrm{HCoVs}$ are reported to have annual peaks of circulation in winter months and few detections in summer months in temperate regions $[9,22,25$, 27]. Our data shown a completely different trend as we found $\mathrm{HCoVs}$ had a summer-autumn peak of activity, suggesting seasonality of $\mathrm{HCoVs}$ in subtropical regions was not restricted to the winter. Individual $\mathrm{HCoV}$ subtypes shown variable circulation throughout each year. During the sampling period of this study, $\mathrm{HCoV}-\mathrm{OC} 43$ was the major circulating strain in 2017, whereas HCoVNL63 predominated in the following two years. This was expected, given previous observations of annual variation in the circulation of HCoVs in Japan [22], United States [9] and Thailand [28]. HCoV-229E was only detected in spring and summer with a comparatively low detection frequency. This reaffirmed with the report in United Kingdom indicating that $\mathrm{HCoV}-229 \mathrm{E}$ was lacking a discernible seasonality [25]. However, continuous surveillance of $\mathrm{HCoV}$ infections over a long period is required to delineate their circulation trend more precisely.

This study investigated children between age below 18 years old. The burden of $\mathrm{HCoV}$ infections in children was high, especially among infants $((<1$ year old $)$ because of their immature immune system. The age distribution of patients varied between $\mathrm{HCoV}$ species. Similar to the epidemiological feature in United States [9], $\mathrm{HCoV}-\mathrm{OC} 43$ detections were most prevalent in infants, while $\mathrm{HCoV}$ 229E infections were most common among elder children. In concordance with a previous study [17], we have also found that boys were more vulnerable $(4.02 \%)$ to $\mathrm{HCoV}$ infections than girls (3.87\%). Specimen types are important for the diagnosis of respiratory viral infections. Although the overall detection rate of $\mathrm{HCoVs}$ was similar between sample types, sputum was superior to bronchoalveolar lavage and nasopharyngeal swab as all $\mathrm{HCoV}$ subtypes were detected from sputum. This finding was consistent with previous reports that sputum was more sensitive than nasopharyngeal swabs for respiratory viral detection $[29,30]$. Although more than half one-third of the $\mathrm{HCoV}$ positive samples were co-detected with other viruses, our data support that $\mathrm{HCoVs}$ lead to a substantial burden of respiratory tract infections in children.

Phylogenetic analysis based on the spike gene confirmed previously published results and illustrated the genetic diversity of $\mathrm{HCoV}$ strains. Recombination occurred in $\mathrm{HCoV}$ frequently. The primary circulating genotypes of $\mathrm{HCoV}-\mathrm{OC} 43$ in our study were $\mathrm{B}$ and $\mathrm{G}$, while none of the genotype A, C, D, E and F were detected. This finding was consistent with Guangzhou strains, where their dominant circulating genotypes were
$B$ and G [31]. The phylogenic tree based on spike gene of HCoV-NL63 revealed the genotypes circulating in Zhejiang area were $B$ and $C$, which was different from Kenya as their circulating genotypes were A and B [32]. However, this database was too small to reflect the actual variation level of HCoVs. Further research is needed to apply whole genome sequencing as the primary sequencing method for the genetic characterization of HCoVs.

To best of our knowledge, this comprehensive survey is the first to describe the clinical patterns and genetic characterization of the four major $\mathrm{HCoVs}$ and SARSCoV-2 in Zhejiang province during a multi-year period. However, some limitations still existed to this survey. We only evaluated respiratory symptoms among hospitalized children, while the data from asymptomatic children or patients with mild respiratory symptoms were not included. Additionally, we assessed $\mathrm{HCoV}$ percent positivity based on the submission of specimen collection. Aggregate data might contain multiple specimens from the same patient, potentially affecting the demographic characteristics of our total study populations. Therefore, our data probably had some bias to represent the overall health burden of HCoVs infections of the general pediatric population in Zhejiang province, China.

\section{Conclusion}

Taken together, this study revealed that human coronaviruses were a significant cause of acute respiratory infections among hospitalized children, especially infants. Individual $\mathrm{HCoVs}$ may show variable circulation from year to year. As the global COVID-19 outbreak continues to grow, more investigations and rigorous surveillance are warranted to ascertain the circulation patterns and molecular epidemiology of human coronaviruses in China.

\section{Abbreviations}

HCoVs: Human coronaviruses; RNA: Ribonucleic acid; SARS-CoV: Severe acute respiratory syndrome coronavirus; SARS-CoV-2: Severe acute respiratory syndrome coronavirus 2; MERS-CoV: Middle east respiratory syndrome coronavirus; HCoV-NL63: Human coronavirus NL63; HCoV-OC43: Human coronavirus OC43; HKU1: Human coronavirus HKU1; HCoV-229E: Human coronavirus 229E; PCR: Polymerase chain reaction; RSVs: Respiratory syncytial viruses; RSVA: Respiratory syncytial virus A; RSVB: Respiratory syncytial virus B; PIV1: Parainfluenza virus 1; PIV2: Parainfluenza virus 2; PIV3: Parainfluenza virus 3; PIV4: Parainfluenza virus 4; HRV: Human rhinovirus; FluA: Influenza virus A; FluB: Influenza virus B; H3N2: FluAlnfluenza virus H3N2; H1N1: Influenza virus H1N1; HBoV: Human bocavirus; ADV: Adenovirus.

\section{Supplementary information}

The online version contains supplementary material available at https://doi. org/10.1186/s12985-021-01562-8. 
Additional file 1. Supplementary table 1. Sequences of oligonucleotides used for molecular analysis.

\section{Acknowledgements}

We greatly appreciate the support from the pathology department of Zhejiang Children Hospital for providing clinical specimens.

\section{Authors' contributions}

LF and LS drafted the manuscript. LS, SY and DZ involved sample collection, clinical data collection and virus detection. YZ, LF and LS participated in spike gene amplification. $Y Z$ and LF interpreted the surveillance and virological data. YZ designed the whole project. HM and YC provided important guidance. All authors reviewed and revised the first and final drafts of this manuscript. All authors read and agreed the final manuscript.

\section{Funding}

This work was funded by Major National Science and Technology Projects in the 13th Five-year Plan (2017ZX10103008-002), Health leading Talents Program of Zhejiang Province (CX-9), China Postdoctoral Science Foundation (2020T130104ZX) and Zhejiang Postdoctoral Science Foundation (ZJ2020027).

\section{Availability of date and materials}

The datasets used and analyzed during the current study are available from the corresponding author on reasonable request.

\section{Declarations}

\section{Ethics approval and consent to participate}

This study was ethically approved by Zhejiang Provincial Center for Disease Control and Prevention of ethics committee. Written informed consent was obtained from the guardians of all participants before the sample and data collection.

\section{Consent for publication}

Not applicable.

\section{Competing interests}

The authors declare that they have no competing interests.

\section{Author details}

${ }^{1}$ Department of Laboratory, School of Medical Technology, Zhejiang Chinese Medical University, Hangzhou 310053, China. ${ }^{2}$ Zhejiang Provincial Center of Disease Control and Prevention, 3399 Bincheng Road, Hangzhou 310051 , China. ${ }^{3}$ Department of Laboratory Medicine, The First Affiliated Hospital, Zhejiang University School of Medicine, Hangzhou 310000, China.

Received: 10 January 2021 Accepted: 21 April 2021

Published online: 30 April 2021

\section{References}

1. Viruses CSGotICoTo. The species Severe acute respiratory syndrome-related coronavirus: classifying 2019-nCoV and naming it SARS-CoV-2. Nat Microbiol. 04 2020;5(4):536-544.

2. Zhu N, Zhang D, Wang W, et al. A novel Coronavirus from patients with pneumonia in China, 2019. N Engl J Med. 2020;382(8):727-33.

3. Hui DS, Azhar E, Madani TA, et al. The continuing 2019-nCoV epidemic threat of novel coronaviruses to global health — the latest 2019 novel coronavirus outbreak in Wuhan. China Int J Infect Dis. 2020;91:264-6.

4. Han Q, Lin Q, Jin S, You L. Coronavirus 2019-nCoV: a brief perspective from the front line. J Infect. 2020;80(4):373-7.

5. Drosten C, Günther S, Preiser W, et al. Identification of a novel coronavirus in patients with severe acute respiratory syndrome. N Engl J Med. 2003;348(20):1967-76.
6. Zaki AM, van Boheemen S, Bestebroer TM, Osterhaus AD, Fouchier RA. Isolation of a novel coronavirus from a man with pneumonia in Saudi Arabia. N Engl J Med. 2012;367(19):1814-20.

7. Su S, Wong G, Shi W, et al. Epidemiology, genetic recombination, and pathogenesis of Coronaviruses. Trends Microbiol. 2016;24(6):490-502.

8. van der Hoek L, Pyrc K, Berkhout B. Human coronavirus NL63, a new respiratory virus. FEMS Microbiol Rev. 2006;30(5):760-73.

9. Killerby ME, Biggs HM, Haynes A, et al. Human coronavirus circulation in the United States 2014-2017. J Clin Virol. 2018;04(101):52-6.

10. Klig JE, Shah NB. Office pediatrics: current issues in lower respiratory infections in children. Curr Opin Pediatr. 2005;17(1):111-8.

11. Griffin MR, Walker FJ, Iwane MK, et al. Epidemiology of respiratory infections in young children: insights from the new vaccine surveillance network. Pediatr Infect Dis J. 2004;23(11 Suppl):S188-192.

12. Jevšnik M, Uršič T, Zigon N, Lusa L, Krivec U, Petrovec M. Coronavirus infections in hospitalized pediatric patients with acute respiratory tract disease. BMC Infect Dis. 2012;12:365.

13. Dominguez SR, Robinson CC, Holmes KV. Detection of four human coronaviruses in respiratory infections in children: a one-year study in Colorado. J Med Virol. 2009;81(9):1597-604.

14. Williams PCM, Howard-Jones AR, Hsu P, et al. SARS-CoV-2 in children: spectrum of disease, transmission and immunopathological underpinnings. Pathology. 2020;52(7):801-8.

15. Li J, Qi S, Zhang C, et al. A two-tube multiplex reverse transcription PCR assay for simultaneous detection of sixteen human respiratory virus types/ subtypes. Biomed Res Int. 2013;2013:327620.

16. Zhu N, Wang W, Liu Z, et al. Morphogenesis and cytopathic effect of SARS-CoV-2 infection in human airway epithelial cells. Nat Commun. 2020;11(1):3910

17. Khor CS, Sam IC, Hooi PS, Quek KF, Chan YF. Epidemiology and seasonality of respiratory viral infections in hospitalized children in Kuala Lumpur, Malaysia: a retrospective study of 27 years. BMC Pediatr. 2012;12:32.

18. Shafik CF, Mohareb EW, Yassin AS, et al. Viral etiologies of lower respiratory tract infections among Egyptian children under five years of age. BMC Infect Dis. 2012;12:350.

19. Kwofie TB, Anane YA, Nkrumah B, Annan A, Nguah SB, Owusu M. Respiratory viruses in children hospitalized for acute lower respiratory tract infection in Ghana. Virol J. 2012;9:78.

20. Calderaro A, De Conto F, Buttrini $M$, et al. Human respiratory viruses, including SARS-CoV-2, circulating in the winter season 2019-2020 in Parma, Northern Italy. Int J Infect Dis. 2021;102:79-84.

21. Chiu SS, Chan KH, Chu KW, et al. Human coronavirus NL63 infection and other coronavirus infections in children hospitalized with acute respiratory disease in Hong Kong, China. Clin Infect Dis. 2005;40(12):1721-9.

22. Matoba Y, Abiko C, Ikeda T, et al. Detection of the human coronavirus 229E, HKU1, NL63, and OC43 between 2010 and 2013 in Yamagata, Japan. Jpn J Infect Dis. 2015;68(2):138-41.

23. Cabeça TK, Granato C, Bellei N. Epidemiological and clinical features of human coronavirus infections among different subsets of patients. Influenza Other Respir Viruses. 2013;7(6):1040-7.

24. Sipulwa LA, Ongus JR, Coldren RL, Bulimo WD. Molecular characterization of human coronaviruses and their circulation dynamics in Kenya, 2009-2012. Virol J. 2016:13:18.

25. Gaunt ER, Hardie A, Claas EC, Simmonds P, Templeton KE. Epidemiology and clinical presentations of the four human coronaviruses 229E, HKU1, NL63, and OC43 detected over 3 years using a novel multiplex real-time PCR method. J Clin Microbiol. 2010;48(8):2940-7.

26. Liu P, Shi L, Zhang W, et al. Prevalence and genetic diversity analysis of human coronaviruses among cross-border children. Virol J. 2017;14(1):230.

27. Vabret A, MourezT, Gouarin S, Petitjean J, Freymuth F. An outbreak of coronavirus OC43 respiratory infection in Normandy, France. Clin Infect Dis. 2003;36(8):985-9.

28. Dare RK, Fry AM, Chittaganpitch M, Sawanpanyalert P, Olsen SJ, Erdman DD. Human coronavirus infections in rural Thailand: a comprehensive study using real-time reverse-transcription polymerase chain reaction assays. J Infect Dis. 2007;196(9):1321-8. 
29. Falsey AR, Formica MA, Walsh EE. Yield of sputum for viral detection by reverse transcriptase PCR in adults hospitalized with respiratory illness. J Clin Microbiol. 2012;50(1):21-4

30. Jeong JH, Kim KH, Jeong SH, Park JW, Lee SM, Seo YH. Comparison of sputum and nasopharyngeal swabs for detection of respiratory viruses. J Med Virol. 2014;86(12):2122-7

31. Zhang SF, Tuo JL, Huang XB, et al. Epidemiology characteristics of human coronaviruses in patients with respiratory infection symptoms and phylogenetic analysis of HCoV-OC43 during 2010-2015 in Guangzhou. PLoS ONE. 2018;13(1):e0191789.
32. Kiyuka PK, Agoti CN, Munywoki PK, et al. Human Coronavirus NL63 molecular epidemiology and evolutionary patterns in rural coastal Kenya. J Infect Dis. 2018:217(11):1728-39.

\section{Publisher's Note}

Springer Nature remains neutral with regard to jurisdictional claims in published maps and institutional affiliations.
Ready to submit your research? Choose BMC and benefit from:

- fast, convenient online submission

- thorough peer review by experienced researchers in your field

- rapid publication on acceptance

- support for research data, including large and complex data types

- gold Open Access which fosters wider collaboration and increased citations

- maximum visibility for your research: over $100 \mathrm{M}$ website views per year

At BMC, research is always in progress.

Learn more biomedcentral.com/submissions 